\title{
Not Hungry Anymore
}

\author{
Nicole Hadler ${ }^{1}$
}

Received: 23 January 2021 / Accepted: 20 April 2021 / Published online: 18 May 2021

(C) Academic Psychiatry 2021

Mix cinnamon into cereal. Swirl. Swirl

Murky liquid, brown wreckage. Dirt.

Continue to swirl. Swirl

Brown clumps cling to the flakes. Sorry specks of earth.

Swirl. Scoop the cereal at the bottom to the top

No piece unscathed. Each one cursed.

Take a bite. Chew

Limp flakes, tongue. Tongue, tissue.

Swallow

Tasteless.

Hear the children's morning chatter below

I do not recognize the tune.

Turn toward the sun's warm greeting

My window is black with dust.

Notice the sky's orange and pink hu-

A concrete building blocks my view.

Take a bite. Chew

Limp flakes, tongue. Tongue, tissue.

Bare, icy feet grip the coarse hardwood floor.

My calloused flesh does not wince or object

To the stale, hardened crumb that stabs at my toe.
Take a b-

No more.

I scrape the soggy heap into the trash,

Inhaling the stench of decaying meals.

Button my yellowed runty coat -

A radiant snowy white not long ago.

Poet's Statement: In this poem, a medical student recounts her experience with burnout and a period of depression during her medical training. It captures the depth of a student's depression by taking the audience through an activity as mundane as eating breakfast, which turns out to be a very difficult task for this student. Her exhaustion and hopelessness overpower the voice of optimism that unsuccessfully attempts to lift her up. She lost sight of why she went into medicine, symbolized by her white coat turning yellow. This poem enhances the reader's awareness that in the field of medicine, we are all human, and no one is immune to suffering from low periods or burnout.

\section{Declarations}

Competing Interests The author declares no competing interests.

Publisher's Note Springer Nature remains neutral with regard to jurisdictional claims in published maps and institutional affiliations.
Nicole Hadler

hadlernl@umich.edu

1 University of Michigan Medical School, Ann Arbor, MI, USA 